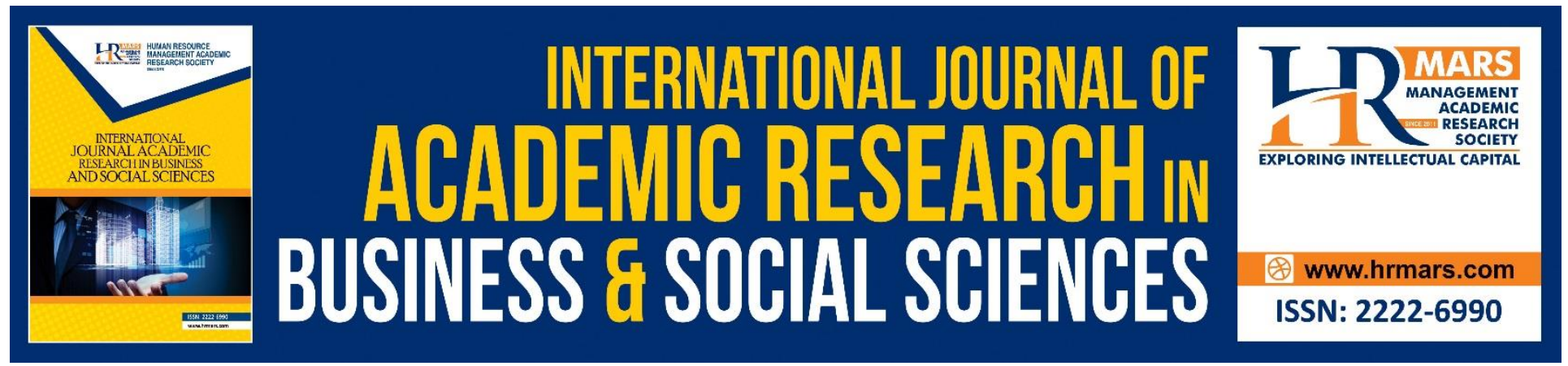

\title{
A Study on Customer Perception towards E-banking: With Special Reference to Urban and Rural Districts in Sri Lanka.
}

\section{Weligodapola Mano, Lokeshwara Anuja, Prashanthy Karunakaran, Sooriyakumaran Subarami, Rubika Sathiyaseelan, Lakmali. G. T. H. D}

To Link this Article: http://dx.doi.org/10.6007/IJARBSS/v10-i10/7766

DOI:10.6007/IJARBSS/v10-i10/7766

Received: 02 August 2020, Revised: 27 August 2020, Accepted: 17 September 2020

Published Online: 20 October 2020

In-Text Citation: (Weligodapola, et al., 2020)

To Cite this Article: Weligodapola, H. W. M. C., Lokeshwara, A. A., Prashanthy, K., Sooriyakumaran, S., Rubika, S., Lakmali, G. T. H. D. (2020). A Study on Customer Perception towards E-banking: With Special Reference to Urban and Rural Districts in Sri Lanka. International Journal of Academic Research in Business and Social Sciences. 10(10), 682-698.

\section{Copyright: (c) 2020 The Author(s)}

Published by Human Resource Management Academic Research Society (www.hrmars.com)

This article is published under the Creative Commons Attribution (CC BY 4.0) license. Anyone may reproduce, distribute, translate and create derivative works of this article (for both commercial and non-commercial purposes), subject to full attribution to the original publication and authors. The full terms of this license may be seen

at: http://creativecommons.org/licences/by/4.0/legalcode

\section{Vol. 10, No. 10, 2020, Pg. 682 - 698}




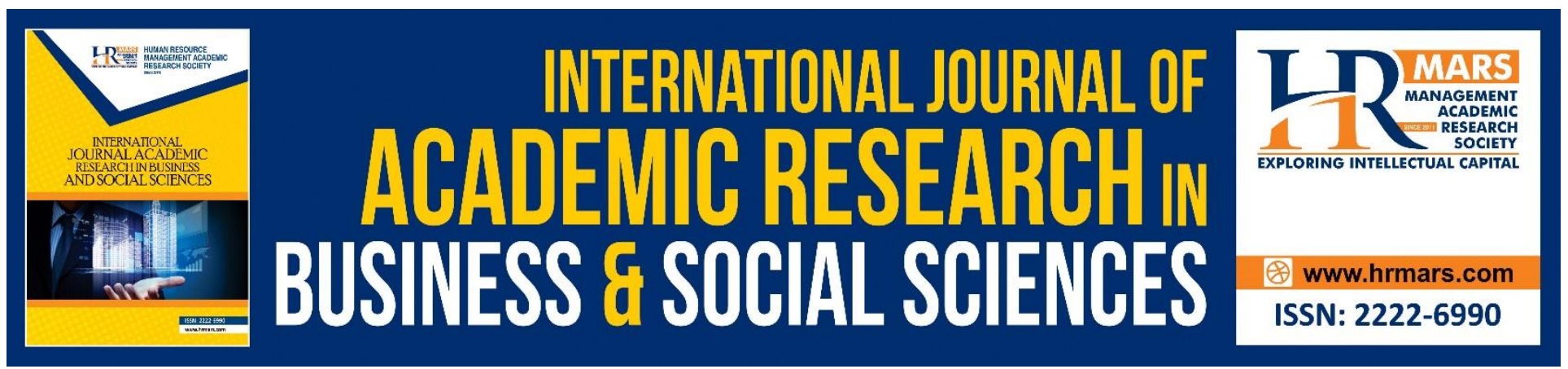

\title{
A Study on Customer Perception towards E-banking: With Special Reference to Urban and Rural Districts in Sri Lanka.
}

\author{
Weligodapola Mano, Lokeshwara Anuja, Prashanthy Karunakaran, \\ Sooriyakumaran Subarami, Rubika Sathiyaseelan, Lakmali. G. T. H. \\ ${ }^{1}$ Senior Lecturer, Business School. Sri Lanka Institute of Information Technology, Malabe, Sri Lanka, \\ ${ }^{2}$ Lecturer, Business School. Sri Lanka Institute of Information Technology, Malabe, Sri Lanka, \\ 3, 4, 5,6 Undergraduate candidate, Business School, Sri Lanka Institute of Information Technology, \\ Malabe, Sri Lanka.
}

Email:mano.w@sliit.lk², anuja.l@sliit.Ik², prashakaruna21@gmail.com³, ramiya.s18@gmail.com4, rubiseelan07@gmail.com ${ }^{5}$,gthdldasilva@gmail.com ${ }^{6}$

\begin{abstract}
This research provides an overview of the customer perception towards E-banking in Sri Lanka, thus highlighting the factors the influence the use of E-banking. The usage of the internet is rapidly increasing in Sri Lanka. However, the usage of E-banking is very low compared to the increase of internet users. In this regard, the analysis will compare the extent of use of E-banking in Sri Lankan rural and urban districts. The study employs both qualitative and quantitative research methods and will be conducted among bank users in Sri Lanka's urban and rural districts. To accomplish the purpose of the study, 390 complete responses were gathered from bank customers who were Ebanking and non-E-banking users by using a convenience sampling method. Through this research, it was identified that the E-banking usage level in the rural region is low compared to the urban region. In addition, findings show that perceived usefulness, perceived ease of use, and awareness of the service are highly influencing factors in the adoption of E-banking among respondents. Like other studies perceived risk and trust, knowledge of the internet and access to the internet, and perceived cost are to be moderately influencing factors. Multi-linear regression analysis was used to apply for this research in order to determine the impact of customer perception on E-banking usage in Sri Lanka. The findings revealed that perceived cost, awareness of the service, and knowledge of internet and access to internet have a significant positive effect on customer perception towards E-banking while perceived usefulness, perceived ease of use, and perceived risk and trust has no significant effect towards E-banking usage according to the results of the study.
\end{abstract}


INTERNATIONAL JOURNAL OF ACADEMIC RESEARCH IN BUSINESS AND SOCIAL SCIENCES Vol. 10, No. 10, 2020, E-ISSN: 2222-6990 @ 2020 HRMARS

Keywords: Electronic Banking (E-banking), E-banking Usage, Customer Perception, Urban and Rural Districts.

\section{Introduction}

The incorporation into the banking sector of new information and communication technologies has had a major effect on consumer services. Indeed, the rate of technical development has a greater effect than any other area on the transformation in the banking industry (Kirakosyan and Danaiata, 2014). E-banking is recognized as one of the most effective and practical business services among the various contemporary information and communication technologies utilized by banks in the world. The rapid advancement in technology helps banks to give consumers banking services through the internet. Adapting to the new technologies help banks to more efficiently and effectively offer its services to its customers. A few years back, it was necessary to visit the bank to make financial transfers. Customers will wait in lengthy lines to conduct banking transfers under the restricted hours of the banking. Because of the emergence of E-banking customers nowadays, they have the facility to do banking transactions without entering the bank. And through this E-banking, customers can carry out transactions from one country to another. E-Banking utilizes the user interface internet browser and the internet to transfer and import data from a programming device, thus reducing maintenance costs. For clients, E-Banking offers 24-hour-a-day access to banking administrations with current data. If the internet connection is available, customers can access to the banking via the banking website (Fathima and Muthumani, 2015).

As reported in the Central Bank Annual Report (2018), currently, 26 licensed commercial banks operating in Sri Lanka, and most of them have E-banking services. The essential services offered by E-banking are: displaying balance in bank account (from home or through branches), check the transaction history, transfer the money to other bank accounts or same bank accounts (Local Banks, Overseas Banks), taking out money via Automated Teller Machines (ATM), transfer of funds to third parties, telebanking, utilization of credit cards and debit cards for payment and transactions, making payments anywhere in the world are being added to these essential services. In developed economies, the rapid growth of E-banking technology is prominent. Most of the banking institutions in the developing world have switched away from traditional forms of banking to conduct transactions over the internet. Most of them have a fully integrated online system; therefore, consumers are expected to enjoy much, if not all, of the perceived benefits of E-banking (Al-Qeisi and Hegazy, 2015). Conversely, in developing countries, the rate of use of E-banking is comparatively lower. Many emerging countries lack a high degree of technological developments evident in developing nations. The attitude and behavior of customers toward E-banking in most developing nations are highly unpredictable (Shaikh and Karjaluoto, 2015).

This research will examine in detail the actual perception of customers embraces E-banking while recognizing the factors connected to the adoption of E-banking in Sri Lanka context by investigating urban and rural districts in Sri Lanka. There are several types of researches related to E-banking adoption conducted in the global and Sri Lankan context but none of them represent the comparison of urban and rural districts in Sri Lanka.

\section{Statement of the Problem}

According to the Central Bank Annual Report (2018), there are 7,263,161 internet and e-mail users out of 21 million population, which represents only $34.5 \%$ of the total population. From that $25 \%$ of 
INTERNATIONAL JOURNAL OF ACADEMIC RESEARCH IN BUSINESS AND SOCIAL SCIENCES Vol. 10, No. 10, 2020, E-ISSN: 2222-6990 @ 2020 HRMARS

the population used desktop or laptop, $70.9 \%$ mobile phones, $2.2 \%$ tablet and $1.9 \%$ are using internet connection. Despite that, the internet usage level has increased, the usage level of E-banking is considerably less, which means monetary transactions made through an electronic device is low. Sri Lanka Department of Census and Statistics (2017), indicates that compared to other age groups, ages between 15 - 34 had a high literacy rate. However, in general, the E-banking usage level between this age category is less when compared to the literacy rate of youth. In Sri Lanka, recent findings illustrate that customers were more reluctant to accept this facility even it has more relative advantages (Nethananthan and Shanmugathas, 2018).

As a developing country, using the concept of E-banking is very necessary and crucial to cope with the world of today. But the number of Sri Lankans using this facility is very limited in their everyday activities. Instead of the traditional system, it seems most of the people dislike using the new system (Kariyawasam and Jayasiri, 2016). When we consider the global level, Sri Lanka's E-banking usage level was considerably low as compared to other developing nations (Shantha, 2019; Nayanajith, Premarathne and Gunatilake, 2016). Given the fact that most individuals are aware of the E-banking service, a significant portion of them did not have any interest in using those facilities. Customers are still following the traditional way to do their transactions such as withdraw money, check balances, bill payments at their bank counters. Since E-banking involves money, individuals are logically hesitant to utilize it on account of the frauds and cheats heard everywhere throughout the world. Therefore, clients would not care to lose their cash even it is an advantageous way (Suraweera et al., 2011). Further, the study revealed that E-banking was used still less than $1 \%$ of Sri Lankan banking customers.

Through these confirmations, it is shown that in Sri Lanka, there is a problem concerning customers who are reluctant to use E-banking even with the expansion of internet use. Therefore, to promote the usage of E-banking, it is important to identify the factors that affect the usage of E-banking. In this manner, this investigation endeavors to give a useful picture of the customers' perceptions on Ebanking in Sri Lanka. Therefore, researchers have decided to focus on chosen urban and rural districts to collect the data to address the following research objectives. The literatures available in this study area does not seem to have discussed the research gap that we found. Therefore, this research would concentrate on contributing to filling the above-mentioned gap by analyzing customer perception on E-banking in both urban and rural districts in Sri Lanka.

\section{Research Objectives}

- To explore the current usage level of E-banking among bank customers in chosen urban and rural districts in Sri Lanka.

- To determine the factors and its impact which influence the usage of E-banking among bank customers in chosen urban and rural districts in Sri Lanka

\section{Literature Review}

\section{E-banking in Sri Lanka}

Sri Lanka is a developing nation that has about 21.37 million population, among them 10.10 million are internet users (Kemp, 2020). It indicates that usage of the internet is rapidly increased throughout the past years. However, the terrible side of E-banking in Sri Lanka is, however it's given the fact that a huge segment of the individuals thought about E-banking administrations, the prevailing piece of them had not been endeavored those services by themselves in Sri Lanka. They still following 
traditional ways to do their banking transactions at bank counters. For example, checking balances, withdraw money, bill payments and, other activities (Jayasiri, Gunawardena and Dharmadasa, 2016). Abeysiriwardhana and Arampola (2019) stated that only a small fraction of the banking population has shown interest in using the E-banking services in Sri Lanka. Although there is a banking service called "E-banking", some people are not aware of this facility. And most people haven't seen the advertisement on E-banking, although they don't have any leaflets or other documentation linked to the bank on the E-banking platform (Shantha, 2019).

Several researches highlighted the fact that within the Sri Lankan context E-banking adoption is not at a higher level except for ATM facility usage (Abeyrathna, 2015; Kariyawasam and Jayasiri 2016; Premarathne and Gunatilake 2016; Suraweera et al., 2011).

Although several other research scholars argued that while Sri Lankan customers are conscious of the same acceptance of E-banking services, it is at a relatively low pace. In general, consumers used to visit bank counters for a variety of transactions despite being able to conduct those transactions over the internet only through a click of their own (Hettiarachchi, 2013). Kumari (2016) indicated that the level of use of E-bank facilities is considerably less than the potential. The researcher also points out that senior academics prefer traditional banking approaches over E-banking. Nevertheless, Weerasekara and Abeygunawardhana (2011) have established that while internet usage is thriving in Sri Lanka at a rapid rate, the use of E-banking is relatively slow, given the increase in internet usage statistics. According to a study conducted by Kumari (2016), it was found that most customers in Sri Lanka depend on private commercial banks as opposed to state banks. As a developing country, it is necessary to adopt E-banking operations compared with developed countries (Kariyawasam and Jayasiri, 2016). Moreover, the study has reported that due to security issues, Sri Lankans are not ready to use E-banking services. According to Premarathne and Gunatilake (2016), there was no relationship between the implementation cost of the E-banking facility and the financial results. According to Jayasiri and Weerathunga (2008), while banks in Sri Lanka are under pressure to move on with the technology, cultural barriers also demotivate customers to turn to E-banking transactions. Premarathne and Gunatilake (2016), however, reported that users of E-banking tend to represent a richer position in Sri Lankan society.

\section{Factors affecting on Customer Perception towards E-banking Adoption}

The reason for understanding consumer preferences is to decide whether consumers approve or reject goods or services, as well as the reasons that cause those decisions. The factors behind the adoption of E-banking will also be discussed in this section. The six main factors driving the acceptance of E-banking are discussed. Those are: Perceived usefulness, Perceived ease of use, Perceived cost, Knowledge of Internet and Access to Internet, Awareness of the service, and Perceived trust and risk.

\section{Perceived Usefulness}

As stated by Davis (1989) perceived usefulness means individual believes that the use of new technology will improve their performance. Xiao et al. (2017) conclusion indicates that the perceived usefulness of E-banking takes precedence over other considerations as most people decide whether to use them. If customers find it convenient, they are much more willing to use E-banking. Yadav (2016) found according to bank customers perceived usefulness is positively associated with Ebanking. Therefore, banks should be widely promoted various benefits of E-banking, which will lead 
INTERNATIONAL JOURNAL OF ACADEMIC RESEARCH IN BUSINESS AND SOCIAL SCIENCES Vol. 10, No. 10, 2020, E-ISSN: 2222-6990 @ 2020 HRMARS

to an increase in the number of subscriptions to banking services via the internet. Goonetilake (2011) found that perceived usefulness has a major impact on the use of E-banking. To get more customers, managers should be improving the usefulness of the banking website system. Most banks in Sri Lanka do not have all facilities on their bank websites. Some of the banks allow their customers only for checking their balance and fund transfer. This will demotivate their customers to involve in the Ebanking service.

\section{Perceived Ease of Use}

Davis (1989) describes the perceived ease of use as the extent to which a person thinks that using a given device should be effortless. Nethananthan and Shanmugathas (2018) revealed that easy to use is one of the reasons for customers adopting advanced technology product or service. If consumers find it difficult to operate they will not use the product or services. Goonetilake (2011) mentions that the perceived ease of use was positively associated with the degree of use of the E-banking. Consumers preferred banks to make banks' websites the simplest and easy way to understand and use. If the banking website is more intricate and difficult to use, Customers do not plan to use Ebanking services. Customers' decision on whether to accept or reject innovation depends on how easy it is used to them. technologies such as E-banking, it must be convenient and easy to use, and the first experiences of customers about the service should be excellent and significant (Zarook, 2010).

\section{Perceived Cost}

Premarathne and Gunatilake (2016) revealed there are two types of costs related to the adoption of E-banking. Firstly, general computer and internet-based costs and secondly, bank charges. If customers use modern technologies, the technologies should be at a reasonable price compared to other alternatives. Otherwise, customers will not adopt the technology. The study's results indicate that cost of internet access and the system cost have a negative impact on E-banking adoption. Aliyu and Tasmin (2012) revealed the relationship between the adoption of E-banking and cost factor. They found consumers accept new technologies only at an affordable price. Consumers who accept Ebanking are aware of the cost and consider it acceptable. It is revealed customers can decide to accept or oppose E-banking is based on their perception of costs. Consumers would think twice before paying for any services. From the customer point of view, if customers do not find any benefits from E-banking compared to traditional banking. They are reluctant to pay for such services (Zarook, 2010). Customers see the cost of telecommunications, the cost of E-banking, the installation cost of the internet as essential in encouraging them to implement E-banking services. But non-E-banking users consider these costs to be higher and more expensive than E-banking users (Wu, 2005).

\section{Knowledge of Internet and Access to Internet}

Rajapakse (2017) study mentions that lack of knowledge on internet access and lack of internet access facilities play a significant role in the negative perception on E-banking. Increasing the opportunities for banking users and knowledge of internet access can be seen as a plan to improve the involvement of more traditional banking customers in the use of E-banking. Availability of computers, quick internet connectivity, and their basic skills are prerequisites for accessing E-banking services, and it is one of the main reasons behind slow E-banking adoption in developing countries (Melnikovas, 2018). Kariyawasam and Jayasiri (2016) in their study few respondents noted that the 
INTERNATIONAL JOURNAL OF ACADEMIC RESEARCH IN BUSINESS AND SOCIAL SCIENCES Vol. 10, No. 10, 2020, E-ISSN: 2222-6990 @ 2020 HRMARS

lack of basic facilities required for the adoption of E-banking. fast, stable internet connection and devices (PC, laptop, smartphone) are the basic facilities expected by customers to adopt E-banking but they have knowledge to access the internet. Also, researchers found few respondents stated that they do not know how to access the internet. This means that owing to lack of facilities, there is a proportion of consumers who know about internet access and E-banking but were hesitant to use Ebanking. If banks are given the right opportunities, this number of individuals can easily be encouraged to use E-banking.

\section{Awareness of the Service}

Shantha (2019) revealed awareness factor has no significant effect on the perception of consumers about E-banking services. Therefore, the banks should launch an awareness campaign to increase consumer awareness about E-banking facilities. Nethananthan and Shanmugathas (2018) revealed that E-banking is an innovative product currently offered by banks. When the consumer becomes aware of the product, customer adoption or E-banking rejection begins. The availability of such a facility should reach consumers. This study found that E-banking users are aware of E-banking. But when consider non-E-banking users $40 \%$ of them are not aware of E-banking and some users never heard of the term "E-banking". Few respondents were surprised when they came to realize that they could pay their bills through E-banking. But the truth has been revealed from non-E-banking users is that due to lack of awareness they were not adopting E-banking. According to them, their bank has not made any awareness about E-banking. In order to attract many customers information on Ebanking must be provided by the bank. That information should include safe, convenient, anywhere at any time, low cost (Sundara and Perera, 2018).

\section{Perceived Trust and Risk}

Omotayo (2020) found trust as an important factor in the use of online transactions because of risks associated with online transactions. It can be speculated that the key explanation for the poor acceptance of E-banking by older people is a lack of trust in E-banking. Elder peoples are aware of their security on online platforms and may not feel that E-banking is completely reliable, as transaction errors may occur due to human error or system failure. Older people need to have some form of safety concern due to the type of loss that could occur with safety. Therefore, customer trust and confidence in using E-banking should be improved by offering a stable and efficient platform. Empirical results have shown that the trust factor to be the most important influence factor of Ebanking. Therefore, the study suggested that the banking industry should develop a better system for security protection and a set of standard operating procedures for potentially harmful attacks and reduce the customer concerns about the security of the internet and E-banking (Lin, et al. 2020). Ibrahim, Sudi and Warsame (2018) found security and privacy of E-banking transactions would impact the acceptance of E-banking. If there is no proper security and privacy, customers will not be accepted to use E-banking services offered through the internet.

\section{Methodology}

In our study authors were incorporated both qualitative and quantitative data. The qualitative analysis focused on secondary data (existing literature) to discern the variables that affect the usage of E-banking. At that point, quantitative research was followed to accomplish the objectives by using questionnaire survey. Since, the research is based on the customer perceptions in selected urban and 
INTERNATIONAL JOURNAL OF ACADEMIC RESEARCH IN BUSINESS AND SOCIAL SCIENCES Vol. 10, No. 10, 2020, E-ISSN: 2222-6990 @ 2020 HRMARS

rural regions in Sri Lanka, the primary data is collected through a well-designed questionnaire survey in three languages (i.e., Sinhala, English, and Tamil). And the survey was distributed in six districts i.e. Colombo, Kalutara, Gampaha, Monaragala, Mannar, and Mullaitivu. The Colombo, Gampaha, Kalutara were selected as Urban districts and Monaragala, Mannar, and Mullaitivu were selected as Rural districts through the method of judgemental sampling. The reason why Colombo, Kalutara, Gampaha were selected as Urban districts and Monaragala, Mannar, and Mullaitivu were selected as Rural districts are as follows: As per the Department of Census and Statistics-Sri Lanka (2012) Colombo, Kalutara and Gampaha have high density population and Monaragala, Mannar, and Mullaitivu have low density population.

The target group is identified as customers who have bank accounts. In order to participate in the survey, the respondents should be bank customers obviously since the non-banking customer doesn't have any intention of using E-banking. Although the banks have complete details of their customers, in order to maintain privacy these banks were not willing to provide the contact details of the customers. In this study, respondents were selected by using convenience sampling which is a nonprobability sampling technique. The purpose of selecting this sampling technique is to collect information conveniently. The reliability and validity of measurement tools were ensured through a pilot study conducted on 30 participants. The first section of the questionnaire is intended to gather specific demographic information from the participants (i.e., age, gender, education, geographical area, occupation, and etc). The second section is about the perception of the respondents about Ebanking. This will review the factors such as awareness of the service, knowledge of internet and access to internet, trust and risk, ease of use, and usefulness which are most frequently cited and emphasized by authors. It was measured on a six-point Likert scale. Further, descriptive and multiple regression analysis were used to test the objectives by using Statistical Package for Social Sciences (SPSS).

\section{Results and Discussion}

At the end of data collection, 433 responses were reported. After a thorough review of all responses, 390 responses were considered to be complete and therefore used for research purposes. As seen in Table 1, this segment shows details collected from the urban and rural areas comprising of 390 bank customers (E-bank users and non-E-bank users), lead up to a response rate of 90\%. Totally, 195 responses were collected from each Urban and Rural region.

Table 1: Respondent rate analysis

\begin{tabular}{|l|l|l|l|}
\hline Region & Districts & Respondents & Percentage \\
\hline \multirow{4}{*}{ Urban } & Colombo & 78 & $18 \%$ \\
\cline { 2 - 4 } & Gampaha & 61 & $14.1 \%$ \\
\cline { 2 - 4 } & Kalutara & 56 & $12.9 \%$ \\
\hline \multirow{3}{*}{ Rural } & Monaragala & 84 & $19.4 \%$ \\
\cline { 2 - 4 } & Mannar & 55 & $12.7 \%$ \\
\cline { 2 - 4 } & Mullaitivu & 56 & $12.9 \%$ \\
\hline
\end{tabular}

Source: Survey data 
INTERNATIONAL JOURNAL OF ACADEMIC RESEARCH IN BUSINESS AND SOCIAL SCIENCES Vol. 10, No. 10, 2020, E-ISSN: 2222-6990 @ 2020 HRMARS

The percentage values and frequencies of the responses to the E-banking use is shown in Table 2. Research results suggest that total urban area responses of 50 percent and rural area responses of 50 percent were reported. As seen in table 2 below, a total of 55.90 percent (218) of the respondents are E-banking users and non-E-banking users are 44.10 percent (172). As we contrasted the results for urban and rural areas, the result indicates that $37.44 \%$ of respondents used E-banking services in urban areas, while only $12.57 \%$ of respondents used E-banking services in rural areas. On the other side, $18.46 \%$ of respondents from the urban region did not use E-banking services, and $31.53 \%$ of respondents from the rural region claimed they never used E-banking services. This showed that the rural area's amount of E-banking use is still low relative to the urban region. Therefore, there is ample empirical evidence to support the anticipated difference in the growth of the E-banking industry between the two regions.

Table 2: E-banking users vs non-E-banking users

\begin{tabular}{|c|c|c|c|c|c|c|c|c|c|c|}
\hline \multirow{2}{*}{\multicolumn{2}{|c|}{ Districts }} & \multicolumn{3}{|c|}{ E-banking Users } & \multicolumn{3}{|c|}{ E-banking Non-Users } & \multicolumn{3}{|c|}{ Total } \\
\hline & & \multirow{2}{*}{$\begin{array}{c}\text { Cou } \\
\mathrm{nt}\end{array}$} & \multirow{2}{*}{$\begin{array}{c}\begin{array}{c}\text { Percent } \\
\text { age }\end{array} \\
15.64 \%\end{array}$} & \multirow{2}{*}{$\begin{array}{c}\begin{array}{c}\text { Cumulat } \\
\text { ive }\end{array} \\
\begin{array}{c}\text { Percent } \\
\text { age }\end{array} \\
15.64 \%\end{array}$} & \multirow{2}{*}{$\begin{array}{c}\begin{array}{c}\text { Cou } \\
\text { nt }\end{array} \\
17\end{array}$} & \multirow{2}{*}{$\begin{array}{c}\begin{array}{c}\text { Percent } \\
\text { age }\end{array} \\
4.36 \%\end{array}$} & \multirow{2}{*}{$\begin{array}{c}\begin{array}{c}\text { Cumulat } \\
\text { ive } \\
\text { Percent } \\
\text { age }\end{array} \\
4.36 \%\end{array}$} & \multirow{2}{*}{$\begin{array}{c}\text { Cou } \\
\text { nt }\end{array}$} & \multirow{2}{*}{$\begin{array}{c}\begin{array}{c}\text { Percent } \\
\text { age }\end{array} \\
20 \%\end{array}$} & \multirow{2}{*}{$\begin{array}{c}\begin{array}{c}\text { Cumulat } \\
\text { ive } \\
\text { Percent } \\
\text { age }\end{array} \\
20 \%\end{array}$} \\
\hline \multirow{3}{*}{$\begin{array}{c}\text { Urba } \\
n\end{array}$} & Colombo & & & & & & & & & \\
\hline & $\begin{array}{l}\text { Gampah } \\
\text { a }\end{array}$ & 47 & $12.10 \%$ & $27.74 \%$ & 14 & $3.59 \%$ & $7.95 \%$ & 61 & $16 \%$ & $36 \%$ \\
\hline & Kalutara & 38 & $9.70 \%$ & $37.44 \%$ & 18 & $4.62 \%$ & $12.57 \%$ & 56 & $14 \%$ & $50 \%$ \\
\hline \multirow{4}{*}{ Rural } & $\begin{array}{l}\text { Monarag } \\
\text { ala }\end{array}$ & 35 & $8.97 \%$ & $46.41 \%$ & 49 & $12.53 \%$ & $25.10 \%$ & 84 & $22 \%$ & $72 \%$ \\
\hline & $\begin{array}{l}\text { Mullaitiv } \\
\mathbf{u}\end{array}$ & 17 & $4.36 \%$ & $50.77 \%$ & 39 & $10 \%$ & $35.10 \%$ & 56 & $14 \%$ & $86 \%$ \\
\hline & Mannar & 20 & $5.13 \%$ & $55.90 \%$ & 35 & $9.00 \%$ & $44.10 \%$ & 55 & $14 \%$ & $100 \%$ \\
\hline & Total & 218 & $55.90 \%$ & & 172 & $44.10 \%$ & & 390 & $100 \%$ & \\
\hline
\end{tabular}

Source: Statistical data collected through the survey

Table 3: Do you currently have access to the Internet?

\begin{tabular}{|c|c|c|c|c|c|c|c|c|}
\hline \multirow{3}{*}{$\begin{array}{c}\text { Access } \\
\text { to the } \\
\text { internet }\end{array}$} & \multicolumn{4}{|c|}{ Urban } & \multicolumn{4}{|c|}{ Rural } \\
\hline & \multicolumn{2}{|c|}{ E-banking users } & \multicolumn{2}{|c|}{$\begin{array}{c}\text { Non-E-banking } \\
\text { users }\end{array}$} & \multicolumn{2}{|c|}{ E-banking users } & \multicolumn{2}{|c|}{ Non-E-banking users } \\
\hline & Count & Percentage & Count & Percentage & Count & Percentage & Count & Percentage \\
\hline Yes & 146 & $74.90 \%$ & 49 & $25.10 \%$ & 72 & $37 \%$ & 123 & $63 \%$ \\
\hline No & 0 & $0.00 \%$ & 0 & $0.00 \%$ & 0 & $0.00 \%$ & 0 & $0 \%$ \\
\hline Total & 146 & $75 \%$ & 49 & $25 \%$ & 72 & $37 \%$ & 123 & $63 \%$ \\
\hline
\end{tabular}


INTERNATIONAL JOURNAL OF ACADEMIC RESEARCH IN BUSINESS AND SOCIAL SCIENCES Vol. 10, No. 10, 2020, E-ISSN: 2222-6990 @ 2020 HRMARS

Source: Statistical data collected through the survey

This section discusses internet access by respondents. In the urban region, both E-banking and NonE-banking users have access to the internet. It indicates 146 respondents who are E-banking users have access to the internet and 49 respondents who are not E-banking users but have internet access in the urban region. In the rural region, 72 respondents who are E-banking users have internet access and 123 respondents who are not E-banking users have internet access. It proved that people reluctant to use E-banking, although internet access is available.

Table 4: How long have you used a computer or smart mobile device?

\begin{tabular}{|c|c|c|c|c|c|c|c|c|}
\hline \multirow{3}{*}{$\begin{array}{l}\text { Computer or } \\
\text { Smart mobile } \\
\text { device usage }\end{array}$} & \multicolumn{4}{|c|}{ Urban } & \multicolumn{4}{|c|}{ Rural } \\
\hline & \multicolumn{2}{|c|}{ E-banking users } & \multicolumn{2}{|c|}{$\begin{array}{c}\text { Non-E-banking } \\
\text { users }\end{array}$} & \multicolumn{2}{|c|}{ E-banking users } & \multicolumn{2}{|c|}{$\begin{array}{c}\text { Non-E-banking } \\
\text { users }\end{array}$} \\
\hline & Count & Percentage & Count & Percentage & Count & Percentage & Count & Percentage \\
\hline Never & 0 & 0 & 0 & $0 \%$ & 0 & $0.00 \%$ & 0 & $0 \%$ \\
\hline Below 1 year & 2 & $1.40 \%$ & 8 & $16.3 \%$ & 4 & $5.6 \%$ & 16 & $13.0 \%$ \\
\hline $1-2$ years & 9 & $6.20 \%$ & 4 & $8.2 \%$ & 8 & $11.1 \%$ & 37 & $30.1 \%$ \\
\hline 3-5 years & 36 & $24.70 \%$ & 12 & $24.5 \%$ & 26 & $36.1 \%$ & 42 & $34.1 \%$ \\
\hline $6-10$ years & 67 & $45.90 \%$ & 20 & $40.8 \%$ & 16 & $22.2 \%$ & 20 & $16.3 \%$ \\
\hline $\begin{array}{l}\text { more than } 10 \\
\text { years }\end{array}$ & 32 & $21.90 \%$ & 5 & $10.2 \%$ & 18 & $25.0 \%$ & 8 & $6.5 \%$ \\
\hline Total & 146 & $100 \%$ & 49 & $100 \%$ & 72 & $100.00 \%$ & 123 & $100 \%$ \\
\hline
\end{tabular}

Source: statistical data collected through the survey

In the urban region, about 146 respondents were E-banking users. Among these users, 45.90\% (67) have used the computer/smart phone for 6-10 years. And about 49 respondents were non-E-banking users. Among these users, $40.8 \%$ (20) respondents have used the computer/smart phone for $6-10$ years. In the rural region, about 72 respondents were E-banking users. Among these users, 36.1\% (26) have used the computer/smart phone for 3-5 years. Further, about 123 respondents were nonE-banking users. Among these users, 34.1\% (42) have used the computer/smart phone for 3-5 years. Therefore, overall, the researchers believe that majority of both E-banking users and non-E-banking users have used computer/smart phone devices. Further, this suggests that Sri Lankans are generally experienced computer/smartphone users.

\section{Reliability Analysis}

Reliability is determined by Cronbach's alpha and is an optimal method to assess a coefficient's reliability. In other words, the Cronbach alpha measures how precisely a latent framework describes a series of perceived variables. Table 5 shows that Cronbach's alpha was high (higher than 0.7) for all variables. This suggests that the questions put in each segment of the questionnaire satisfy cronbach's specificity and are suitable for factor estimation. 
INTERNATIONAL JOURNAL OF ACADEMIC RESEARCH IN BUSINESS AND SOCIAL SCIENCES Vol. 10, No. 10, 2020, E-ISSN: 2222-6990 @ 2020 HRMARS

Table 5: Reliability test

\begin{tabular}{|l|c|}
\hline Factor & Cronbach's Alpha \\
\hline Perceived usefulness & 0.943 \\
\hline Perceived ease of use & 0.952 \\
\hline Perceived cost & 0.894 \\
\hline Awareness of the service & 0.912 \\
\hline Knowledge of internet and access to internet & 0.866 \\
\hline Perceived risk and trust & 0.896 \\
\hline Total & 0.942 \\
\hline
\end{tabular}

Source: Statistical data collected through the survey

Table 6: Major factors influencing the adoption of E-banking

\begin{tabular}{|l|c|c|}
\hline Factor & Mean & St. Deviation \\
\hline Perceived usefulness & 4.18 & 1.110 \\
\hline Perceived ease of use & 3.79 & 1.161 \\
\hline Perceived cost & 3.35 & 1.097 \\
\hline Awareness of the service & 3.47 & 1.151 \\
\hline Knowledge of internet and access to internet & 2.89 & 1.148 \\
\hline Perceived risk and trust & 3.04 & 1.189 \\
\hline
\end{tabular}

Source: Statistical data collected through the survey

Both urban and rural survey respondents were asked to assess their view of factors affecting Ebanking acceptance, and the findings are presented in Table 6. On a 6-point scale, perceived usefulness, ease of use, and service awareness are regarded as highly relevant factors among bank customers with a mean value of $4.18,3.79$, and 3.47 respectively, which can be interpreted as respondents believe these factors play a vital role in the adoption of e-banking. Furthermore, the system's flexibility allows transactions to be effectively carried out as consumers who use E-banking do not have to stand in queues or wait for their turns at the counters; E-banking can be accessed from any location at any time round the clock compared to traditional banking. And once consumers are aware of the integrated and reliable services offered everywhere, they are likely to turn to the service providers. This will increase the use of E-Banking. Thus, perceived usefulness, perceived ease of use, and service awareness can help in the adoption of E-banking, which is also proven by the survey. The mean value of knowledge of internet and access to internet is 2.89 , which is placed between the disagreed level to neutral level but somewhat closer to the level of the neutral scale. It suggests respondents felt indifferent (neutral) towards internet knowledge and internet access. It indicates 'lack of access to internet' and 'need for personal computer/smart phone' are not perceived as significant barriers to adopt E-banking among the respondents belonging to the rural region. Similarly, the mean perceived risk and trust is 3.04 which is placed closer to the neutral level. It indicates that respondents' trust in E-banking service is in neutral. Some people believe their confidence in the E-banking service is not as strong as that of the bank's offline services. Others don't have much trust in E-banking services is that customers generally have enhanced security expectations due to the complexity of the financial sector and internet-related risk. 
INTERNATIONAL JOURNAL OF ACADEMIC RESEARCH IN BUSINESS AND SOCIAL SCIENCES Vol. 10, No. 10, 2020, E-ISSN: 2222-6990 @ 2020 HRMARS

Finally, multiple regression analysis is conducted to determine the impact of customer perception on E-banking usage in Sri Lanka. The output will be in the form:

\section{$Y=\beta_{0}+\beta_{1} \times 1+\beta_{2} \times 2+\beta_{3} \times 3+\beta_{4} \times 4+\beta_{5} \times 5+\beta_{6} \times 6$}

Here $Y$ is E-banking usage i.e. dependent variable. $\beta_{1}, \beta_{2}, \beta_{3} \ldots . . . B_{6}$ are predictors i.e. Independent variables such as; perceived usefulness, perceived ease of use, perceived cost, awareness of the service, knowledge of internet and access to internet, and perceived risk and trust. $\beta O$ is a constant value of $Y$ when all $\beta$ values are zero.

Table 7: Table indicating $r$ and $r$ square value

\begin{tabular}{|l|r|r|r|r|}
\hline Model & $\mathbf{R}$ & R Square & Adjusted R Square & $\begin{array}{c}\text { Std. Error of the } \\
\text { Estimate }\end{array}$ \\
\hline 1 & $0.540^{\mathrm{a}}$ & 0.292 & 0.233 & 0.435 \\
\hline
\end{tabular}

a. Predictors: (Constant), Perceived risk and trust, Perceived usefulness, Perceived cost, Awareness of the service, Knowledge of internet and access to internet, Perceived ease of use

Source: Statistical data collected through the survey

The use of E-banking is the dependent variable and the perceived usefulness, perceived ease of use, perceived cost, awareness of the service, knowledge of internet and access to internet, and perceived risk and trust are independent variables. Table 7 above reveals that the coefficient estimate is 0.292. Therefore, the independent variables describe approximately 29.2 percent of the difference in the use of E-banking. In making forecasts, the regression equation appears to be very useful, as the $\mathrm{R}^{2}$ value is 0.292 . From the above table, $R=0.540, R^{2}=0.292$ and adjusted $R$ square $=0.233$ with standard error 0.435 mean that the discrepancy of 29.2 percent over the dependent variable i.e. banking use was explained by six different variables concerning the introduction of E-banking. As shown below, it contributes to searching for the regression model.

Table 8: Anova showing f-value and sig-value of the impact of customer perception

\begin{tabular}{|c|c|c|c|c|c|c|}
\hline \multicolumn{2}{|c|}{ Model } & \multirow{2}{*}{$\begin{array}{l}\begin{array}{l}\text { Sum of } \\
\text { Squares }\end{array} \\
28.081\end{array}$} & \multirow{2}{*}{$\begin{array}{r}\text { df } \\
30\end{array}$} & \multirow{2}{*}{$\begin{array}{r}\text { Mean Square } \\
0.936\end{array}$} & \multirow{2}{*}{$\begin{array}{l}\text { F } \\
4.937\end{array}$} & \multirow{2}{*}{$\begin{array}{l}\text { Sig. } \\
.000^{\mathrm{b}}\end{array}$} \\
\hline 1 & Regression & & & & & \\
\hline & Residual & 68.063 & 359 & 0.190 & & \\
\hline & Total & 96.144 & 389 & & & \\
\hline \multicolumn{7}{|c|}{ a. Dependent Variable: E-banking usage } \\
\hline & s of the ser & owledge of & & & & \\
\hline
\end{tabular}

Source: Statistical data collected through the survey

This means that the overall model was a good fit, and there was a statistically meaningful link between the perception of customers and the use of E-banking. Therefore, it can be argued that the customer perception has a significant influence on the use of E-banking. It shows that the regression fit is pretty good, and the variables used can model the customer perception to a good degree. 
INTERNATIONAL JOURNAL OF ACADEMIC RESEARCH IN BUSINESS AND SOCIAL SCIENCES Vol. 10, No. 10, 2020, E-ISSN: 2222-6990 @ 2020 HRMARS

Table 9: Table indicating value for unstandardized and standardized coefficients

\begin{tabular}{|c|c|c|c|c|c|c|}
\hline \multirow{2}{*}{\multicolumn{2}{|c|}{ Model }} & \multicolumn{2}{|c|}{$\begin{array}{l}\text { Unstandardized } \\
\text { Coefficients }\end{array}$} & \multirow{2}{*}{$\begin{array}{c}\begin{array}{c}\text { Standardized } \\
\text { Coefficients }\end{array} \\
\text { Beta } \\
\end{array}$} & \multirow[b]{2}{*}{$\mathbf{t}$} & \multirow[b]{2}{*}{ Sig. } \\
\hline & & B & Std. Error & & & \\
\hline \multirow[t]{7}{*}{1} & (Constant) & 1.022 & 0.103 & & 9.913 & 0.000 \\
\hline & Perceived usefulness & 0.005 & 0.026 & 0.011 & 0.197 & 0.844 \\
\hline & Perceived ease of use & -0.039 & 0.028 & -0.092 & -1.427 & 0.154 \\
\hline & Perceived cost & 0.098 & 0.023 & 0.217 & 4.193 & 0.000 \\
\hline & Awareness of the service & -0.057 & 0.024 & -0.133 & -2.341 & 0.020 \\
\hline & $\begin{array}{l}\text { Knowledge of internet } \\
\text { and access to internet }\end{array}$ & 0.124 & 0.026 & 0.289 & 4.737 & 0.000 \\
\hline & Perceived risk and trust & 0.011 & 0.026 & 0.026 & 0.401 & 0.688 \\
\hline
\end{tabular}

a. Dependent Variable: E-banking usage

Source: Statistical data collected through the survey

From the above-mentioned statistical table 9, the estimated regression equation is:

E-banking usage $=1.022$ (constant) +0.005 (Perceived usefulness) -0.039 (Perceived ease of use) + 0.098 (Perceived cost) -0.057 (Awareness of the service) +0.124 (Knowledge of internet and access to internet) +0.011 (Perceived risk and trust).

Table 9 shows that the perceived usefulness regression coefficient yielded a result of $p=0.844$, which may not have a substantial effect on the use of E-banking. The ease of use regression coefficient value yielded a result of $p=0.154$, which is not significant unless the significance range exceeds $p<0.05$. This indicates that the perceived ease of use does not have a significant effect on the use of E-banking. The third factor, perceived cost coefficient value yielded a result of $p=0.000$ which is significantly impact on E-banking usage. Similarly, awareness of the service and knowledge of internet and access to internet regression coefficient value yielded a result of $p=0.020$ and $p=0.000$ respectively. It indicates that both factors affect E-banking usage positively and significantly. The last factor, perceived risk and trust significance value is 0.688 which is not significant because the level of significance is greater than $p>0.05$. It implies that perceived risk and trust have no significant impact on the use of E-banking.

\section{Conclusion with Policy Implications}

The overall study is conducted to explore the current level of E-banking use among bank customers in selected urban and rural districts in Sri Lanka, recognize factors affecting E-banking use among Sri Lankan banking customers, and ascertain the effect of consumer expectations on Sri Lankan Ebanking use. By referring to the previous studies and other literature sources six factors (perceived cost, service awareness, internet knowledge and internet access, perceived trust and risk, perceived ease of use and perceived usefulness) were selected as independent variables affecting E-banking adoption in urban and rural districts. As a developing country using the concept of E-banking is essential and important to compete with the world of today. But the number of Sri Lankans who use this concept is, unfortunately, very low in their daily activities compared to internet usage. The survey 
outcome indicates the degree of E-banking usage in Rural at a low level compared with the Urban areas. It has been, however, a vital need for rural area to introduce E-banking services to cope with the rest of the regions. It helps managers to understand variables that influence the use of E-banking and promote the use of technology and improve the general adoption for users of new networking platforms who have now accepted this platform. It is important that banks take initiatives to raise awareness among customers, especially districts that have not used their capabilities. Managers should provide their clients with knowledge regarding the E-banking services and the advantages they gain by utilizing E-banking. Therefore, effective communication strategies should be introduced to increase knowledge of E-banking facilities in the Rural area. For that, banks should publish advertisements to raise awareness of E-banking. Throughout the branch premises, the banks will have many computers organized and show how customers can do E-banking transactions via internet. It will clarify to the customers about the use and advantages that the E-banking facility will offer.

The highly influencing factor on customer perception towards E-banking is perceived usefulness, perceived ease of use and service awareness based on the results. This implies that if clients of banks view E-banking as a convenient, simple and easier means of performing financial transactions than conventional branch banking, the services would be embraced or used. Perceived risk and trust, internet knowledge and internet access, and perceived cost have neutral scale. It indicates that respondents felt that these factors had a moderate influence on customer perception towards Ebanking. Therefore, the managers will also increase the usefulness of E-banking website to enable the customers to utilize the facility. In addition, banks will expand their electronic banking operations, and consumers can be able to utilize E-banking. Further, if customers do not realize how to navigate the forms while signed up with the E-banking platform, and if issues are found when searching the website, consumers will get a negative feeling about the E-banking website. Thus, the website should be designed in an interactive way to capture the attention of the customer. The wording and content on the website should be clear and up to date at any given time. It should be consistent, and understandable. The perceived cost, awareness of the service, and knowledge of internet and access to internet have a significant positive impact on consumer perception towards E-banking while perceived usefulness, perceived ease of use, and perceived risk and trust have no significant effect on e-banking use according to the study findings. Researchers found that to improve the use of Ebanking, all the significant factors are important. Therefore, it is better for banks to take steps to improve the features and facilities concerning these factors.

\section{Contribution of the Study}

From a theoretical point of view, by analyzing customer perception towards E-banking in urban and rural districts in Sri Lanka, this study contributes to the body of knowledge in extending current literatures. Nowadays, the country is facing challenges due to Covid-19, in which banks have reduced their branch opening hours and recommend using online banking to their customers. However, a question that has arisen during the current situation is whether the people are following the trend or not. Therefore, in the further research section researchers have given an idea as to how much is the increment of E-banking services compared to pre covid situations. This would also allow banks to promote exposure to banking services with better protection and accessibility through digital platforms. The past researches have not addressed the comparative study of customer perception on E-banking in the urban and rural region in Sri Lanka. Therefore, this study would fill the knowledge gap and researchers will be able to use the findings used in this analysis for future studies relating to 
INTERNATIONAL JOURNAL OF ACADEMIC RESEARCH IN BUSINESS AND SOCIAL SCIENCES Vol. 10, No. 10, 2020, E-ISSN: 2222-6990 @ 2020 HRMARS

E-banking usage. Apart from theoretical values, the identifying factors influencing E-banking adoption and knowing their relationships can help banks react to the views of their customers and answer the needs of their customers. Besides, this study seeks to segment and profile urban and rural customers according to their perception towards E-banking usage. Banks can develop effective marketing strategies to the dimensions identified thus capturing more customers. In other words, It will help banks to develop their business after completing its research by require managers to understand factors impacting the use of E-banking to improve the use of technology and raise the overall adoption of new connectivity platforms for customers who have now accepted this program. Importantly, banks should take initiatives to raise awareness among customers in particular districts who have not utilized its capabilities. After identifying the factors, it will give banks more insights as to what needs to be changed to take more people on board with E-banking. Changes could be adapted for policy frameworks, perceptions once identified will be giving proper insights for banks to touch the consumers' soft or requirements of sensitive nature as to why they are reluctant in joining this.

\section{References}

Al-Qeisi, K., and Hegazy, A. (2015). Consumer online behaviour: A perspective on internet banking usage in three non-western countries. Procedia economics and finance, 23, 386-390.

Aliyu, A., and Tasmin, R. (2012). The Impact of Information and Communication Technology on Banks "Performance and Customer Service Delivery in the Banking Industry. International Journal of Latest Trends in Finance and Economic Sciences, 2(1), 80-90.

Abeyrathna, B. G. C. M. (2015). A Study on the Nature of the Customers Who Used IT Driven Banking Services of Commercial Banks. In Peradeniya Economics Research Symposium 2015.

Abeysiriwardhana, S., and Arampola, B. (2019). Factors Affecting Internet Banking Usage Behaviour of Urban Youth in Kandy Factors Affecting. International Conference on Management and Economic, 107-120.

Central Bank Annual Report. (2018). Retrieved from: <https://centralbank.ie/docs/defaultsource/publications/corporate-reports/annual-reports/2018-central-bank-annualreport.pdf?sfvrsn=19> [Accessed 28 March 2020].

Department of Census and Statistics-Sri Lanka (2012). Census of Population and Housing 2012. Retrieved from: <http://www.statistics.gov.lk> [Accessed 22 April 2020].

Department of Census and Statistics-Sri Lanka (2017) Literacy rate of youth. Retrieved from: <http://www.statistics.gov.lk> [Accessed 22 April 2020].

Davis, F. D. (1989) Perceived Usefulness, Perceived Ease of Use, and User Acceptance of Information Technology. MIS Quarterly. 13(3), 319-340. Retrieved from: <https://www.researchgate.net/profile/Fred_Davis2/publication/200085965_Perceived_Us efulness_Perceived_Ease_of_Use_and_User_Acceptance_of_Information_Technology/links/ 54934b350cf286fe31268d8d.pdf> [Accessed 28 March 2020].

Fathima, Y. A., and Muthumani, S. (2015). User acceptance of banking technology with special reference to internet banking. Journal of Theoretical and Applied Information Technology, 73(1).

Goonetilake, M. D. D. T. (2011). An Analysis of Consumer Acceptance of E-Banking in Sri Lanka, Master thesis, University of Sri Jayewardenepura. Retrieved from: <http://dr.lib.sjp.ac.lk/handle/123456789/5346> [Accessed 16 March 2020]. 
INTERNATIONAL JOURNAL OF ACADEMIC RESEARCH IN BUSINESS AND SOCIAL SCIENCES Vol. 10, No. 10, 2020, E-ISSN: 2222-6990 @ 2020 HRMARS

Hettiaarachchi, H. A. H. (2013). "Factors Affecting to Customer Adoption of Internet Banking" Kelaniya Journal of Management. Retrieved from: https://kjm.sljol.info/ [Accessed 16 March 2020].

Ibrahim, A. A., Sudi, F. A., and Warsame, S. A. (2018). Factors Affectiong the Adoption of Internet Banking in Mogadishu- Somalia Commercial Banks.

Jayasiri, N., and Weerathunga, W. (2008). Popularity of E-Banking in Sri Lanka. 314-323. Retrieved from:

<https://pdfs.semanticscholar.org/c5d9/eddcbad152a448e9eae4b871b26023a2fc06.pdf?_g $a=2.101128961 .1874290014 .1592634662-1509263637.1585307022>$ [Accessed 20 June 2020].

Jayasiri, N. K., Gunawaradana, K. D., and Dharmadasa, P. (2016). Adoption of Internet Banking in Sri Lanka: An Extension to Technology Acceptance Model. Asia Pacific Institute of Advanced Research, 2(1), 179-189. Retrieved from:

<https://www.researchgate.net/publication/318929808_ADOPTION_OF_INTERNET_BANKIN G_IN_SRI_LANKA_AN_EXTENSION_TO_TECHNOLOGY_ACCEPTANCE_MODEL>[Accessed: 26 March 2020].

Kariyawasam, N. J., and Jayasiri, N. K. (2016). Awareness and Usage of Internet Banking Facilities in Sri Lanka. International Journal of Scientific Research and Innovative Technology, 3(6), 173190.

Kirakosyan, K., and Danaiata, D. (2014). Communication management in electronic banking. Better communication for better relationship. Procedia-Social and Behavioral Sciences, 124, 361 370.

Kumari, J. P. (2016). A Study of Online Banking Usage among University Academics. Social Sciences, $18(18.75), 32$.

Kemp, S. (2020). Digital Sri Lanka. Retrieved from: https://datareportal.com/reports/digital-2020sri-lanka [Accessed 4 September 2020].

Lin, W. R., Wang, Y. H., and Hung, Y. M. (2020). Analyzing the factors influencing adoption intention of internet banking: Applying DEMATEL-ANP-SEM approach. PLOS ONE, 15(2).

Melnikovas, A. (2018). Towards an explicit research methodology: adapting research onion model for futures studies. Journal of Futures Studies, 23(2), 29-44.

Nethananthan, S., and Shanmugathas, S. (2018). Exploring The Factors Influencing Adoption of Internet Banking in Jaffna District. International Journal of Recent Scientific Research, 9(4), 26405-26415.

Omotayo, F. O. (2020). Use and Non-Use of Internet Banking Among Elderly People in Nigeria. International Journal of Social Sciences and Management, 7(2), 42-54.

Shantha, A. A. (2019). Customer Perception on Internet Banking: With Special Reference to Bank of Ceylon in Sri Lanka. International Journal of Research in Engineering, 9(5), 269-280.

Premarathne, W., and Gunatilake, M. (2016). Consumer Adoption of Internet Banking in Sri Lanka. International Journal of Advanced Research, 4(11), 58-765.

Rajapakse, D. R. P. C. R. (2017). E-Banking: A Review of Status, Implementation, Challenges and Oppotunities. International Journal of Economics, Business and Management Research, 1(5), 386-408.

Suraweera, T., Kahingala, S., Batepola, A., Punchihewa, M., Senevirathna, K., and Kahandawaarachchi, C. (2011). IT Driven Banking Services in Sri Lanka: Customer Acceptance 
INTERNATIONAL JOURNAL OF ACADEMIC RESEARCH IN BUSINESS AND SOCIAL SCIENCES

Vol. 10, No. 10, 2020, E-ISSN: 2222-6990 @ 2020 HRMARS

and Service Quality. Retrieved from:

<https://pdfs.semanticscholar.org/986d/7006d41e123d9da9cc219d43570768659161.pdf> [Accessed 28 March 2020].

Sundara, A., and Perera, A. (2018). The Factors Influencing On the Customer Adoption of Internet Banking System Special Reference to the Sampath Bank in Colombo District. International Journal of Scientific and Research Publications, 8(2), 83-107.

Shaikh, A. A., and Karjaluoto, H. (2015). Mobile banking adoption: A literature review. Telematics and Informatics, 32(1), 129-142.

Weerasekara, S., and Abeygunawardhana, P. K. W. (2011). An empirical study on slow and limited adoption of Internet Banking by Sri Lankan customers. International Conference on Industrial and Information Systems. Retrieved from:

<https://www.researchgate.net/publication/252048956_An_empirical_study_on_slow_and _limited_adoption_of_Internet_Banking_by_Sri_Lankan_customers> [Accessed 26 March 2020].

$\mathrm{Wu}$, J. (2005). Factors that influence the adoption of internet banking by South Africans in the eThekwini metropolitan region. Retrieved from:

<http://openscholar.dut.ac.za/handle/10321/114> [Accessed 16 June 2020].

Xiao, Y., Sukumar, A., Tipi, L., and Edgar, D. (2017). Factors Influencing People's Intention to Adopt E-Banking: An Empirical Study of Consumers in Shandong Province, China. Asian Journal of Computer and Information Systems, 5(3), 26-43.

Yadav, P. (2016). Active Drivers of Adoption of Internet Banking. Independent Journal of Management and Production. 7(2), 445-464. Available at:

<https://pdfs.semanticscholar.org/686c/aceb7d8bf17d6f3b3d968c5efa870fd96204.pdf> [Accessed 20 June 2020].

Zarook, M. S. (2010). 'Barriers affecting Internet users from adopting Internet banking in Sri Lanka'. Retrieved from:

<https://dagda.shef.ac.uk/dispub/dissertations/200910/External/Mzarook_Zarook_0901326 58.pdf> [Accessed 28 June 2020]. 